\title{
28 Research Square \\ (Pro)renin receptor: An emerging biomarker and target for fighting cancer
}

Juan Wang

Akira Nishiyama

Makoto Matsuyama

Zhiyu Wang

Ying Yuan

\section{Video Byte}

Keywords: Cell Communication and Signaling, The Second Affiliated Hospital of Zhejiang University School of Medicine, (pro)renin receptor, cancer, Wnt/ $\beta$-catenin signaling pathway, RAS, biomarker, cancer targeted therapy, therapeutic, tumorigenesis, The Cancer Genome Atlas, Genotype-Tissue Expression, diagnosis, treatment, ATP6AP2, ligand, tumor, onco-protein, oncogenesis, pathology

Posted Date: October 28th, 2020

DOI: https://doi.org/10.21203/rs.3.rs-99174/v1

License: (c) (i) This work is licensed under a Creative Commons Attribution 4.0 International License. Read Full License 


\section{Abstract}

(Pro)renin receptor, or (P)RR, is a cell receptor expressed throughout the body. Historically, knowledge about (P)RR has been limited to its functions in the heart and kidneys. But now, growing evidence suggests $(P)$ RR plays a major role in various cancers. Over the last 5 years, researchers have discovered that certain cancers produce abnormally high amounts of (P)RR . which can trigger the formation of tumors in the pancreas, colon, and brain. A recently published review outlines the numerous newly recognized roles of $(P) R R$ in cancer. as well as ways that $(P) R R$ can be used against cancer. including as a target for monoclonal antibody therapy. To read the full review, visit biosignaling.biomedcentral.com 